\title{
Response of Local rice cultivar to Zinc and Boron application
}

\author{
Aram A. Mohammed* Ghafoor A. Mam Rasul $* *$ \\ Akram O. Esmail****
}

Received 21, September, 2008

Accepted 25, April, 2010

\begin{abstract}
:
Five levels of Zn-EDTA fertilizer and foliar application of boron were used to study the local rice response through studying of some vegetative and reproductive growth characters, by conducting two field experiments at Kanipanka Agricultural Research Station during the summer season of 2004 by using RCBD with three replications. Significant differences were found in studied characters, there were increase in the number of days from seeding to 50\% flowering (94.330-96.233) days, from 50\% flowering to physiological maturity (37.50-38.28) days, plant height (82.50-91.423) $\mathrm{cm}$ and LAI (5.441-7.525). Reproductive characters such as number of grains panicle $^{-1}$ (74.11-85.88), number of panicles $\mathrm{m}^{-2}$ (321.00-426.083), biological yield (8166.166-11082.600) $\mathrm{kg} \mathrm{ha}^{-1}$ and yield which increased from 3101.333 to $3862.166 \mathrm{~kg} \mathrm{ha}^{-1}$ as $\mathrm{Zn}$ level increased from $\mathrm{f}_{\mathrm{o}}$ to $\mathrm{f}_{5}$, but in exp. No 2 although final yield increased from 3100.333 to $3791.500 \mathrm{~kg} \mathrm{ha}^{-1}$, but there was increasing in sterility\% from 15 for $\mathrm{f}_{\mathrm{o}}$ to 27 for $\mathrm{f}_{5}$ with boron foliar application. Results of the study indicate to positive response of local rice cultivars to zinc application due to the lack in zinc availability in sulaimani region.
\end{abstract}

\section{Key words EDTA, Zn, B, local rice}

\section{Introduction:}

The essential elements (including major elements) are needed and must be presented in the soils in optimum amounts and in available forms to rice plant [1]. Zn deficiency is more common under the conditions of high $\mathrm{pH}$, calcareous, light and sandy soils, high phosphorous levels, and wet soils, availability of $\mathrm{Zn}$ in the soils correlated negatively with soil $\mathrm{pH}$ and $\mathrm{CaCO}_{3}$ content and positively with clay content [2]. Crops under these soil conditions may suffer from zinc deficiency. $\mathrm{Zn}$ is essential for several metabolic processes in the rice plant, such as cytochrome and nucleotide synthesis, auxin metabolism, chlorophyll production, enzyme activation, and membrane integrity [3].

The results of [4] indicated that $\mathrm{Zn}$ deficiency decreases leaf photosynthetic capacity primarily by reducing the number of PSII units per unit leaf area, and also reducing the photochemical capacity of the remaining PSII units. [5] studies indicated that under severe $\mathrm{Zn}$ deficiencies, tillering decreases or could stop completely, and time to crop maturity was extended, with spikelet sterility in rice increased. The critical range of zinc in soil differs according to soil and plant height. Zinc available for plant in different Iraqi soils ranged between $0.4-3.0 \mathrm{mg}$ $\mathrm{kg}^{-1}$ soil $[6,7,8]$. Zn may be present in the soil, but not available to plants. The chemical analysis of the soils of

*Field Crops Dep. College of Agriculture Univ. of Sulaimani

**Soil and Water Science Dep. College of Agriculture Univ. of Sulaimani

*** Soil and Water Science Dep. College of Agriculture Univ. of Salahadeen 
Kurdistan region done by FAO has shown $\mathrm{Zn}$ deficiency in the soils of Sulaimani, Dohok and Erbil [9].

It was found that cereal crops respond to $\mathrm{Zn}$ application, which cause increase in dry matter yield in calcareous soils $[10,11]$. There were increases in grain yield and straw yield with $\mathrm{Zn}$ application [12,13,14]. The results obtained by [15] indicted that applied $\mathrm{ZnSO}_{4}$ seems to be appropriate and useful to get more paddy yield with better quality kernels, number of panicle bearing tillers, number of spikelets per panicle, 1000 grain weight(g), paddy and straw yields, and sterility\%. Due to the nature of most Iraqi soils which contain (10-35\%) lime, and with $\mathrm{pH}$ above 7.0 most plants are expected to respond to zinc application [16]. Zinc deficiencies are most commonly corrected by application of the zinc fertilizer to the soil, zinc chelates are organic sources of zinc in which the zinc ions are protected by a claw-like chemical ring, this reduces the possibility of zinc being tied-up with phosphates and carbonates in the soils [3].

Boron like $\mathrm{Zn}$ is a micronutrient necessary for plant growth; it regulates transport of sugars through membranes, cell division, cell development, and auxin metabolism. Boron deficiency is wide spread in many Asian countries, it is more common in volcanic soils and calcareous soil, in annual crops, a common result of Boron deficiency in all crops is interruption in flowering, fruiting and the $50 \%$ decrease in yield may, rice sterility $\%$ may related in part to micro nutrient efficiency especially B availability in case of calcareous nature and high $\mathrm{pH}$ of the local soil. Foliar applications may sometimes be more effective than applying boron to the soil, foliar sprays of borax of only
$50 \mathrm{~g} \mathrm{ha}^{-1}$ at the strategic times of flower development and pod set, were as effective method in correcting boron deficiency [17].

The aim of the present study is improving the production and yield of local rice cultivar, since it suffers from low level production and limited apportunity of water source and horizontal expanding.

\section{Materials and Methods:}

This study was conducted during summer season of 2004 at Kanypanka Agricultural Station (580 masl $35^{\circ} 22^{\prime} 37^{\prime \prime} \mathrm{N} \quad 45^{\circ} 43^{\prime} 33^{\prime \prime}$ E) by implementing two different experiments. The experiments were set up as R.C.B.D using local rice cultivar (Banixellan) and five rates of $\mathrm{Zn}$ EDTA $\left(0,12,24,36,48 \mathrm{~kg} \mathrm{Zn} \mathrm{ha}^{-1}\right.$, with three replications, The second experiment included zinc levels and the foliar application of $50 \mathrm{~g} \mathrm{ha}^{-1}$ borax at the beginning of flowering stage., some soil physical and chemical analysis were conducted shown in table (1). Agricultural processes included two opposite direction cultivation, as well as land smoothing and leveling, the plots were sown with seeding rate of $120 \mathrm{~kg} \mathrm{ha}^{-1}$ by direct seeding and $80 \mathrm{~kg} \mathrm{ha}^{-1}$ Nitrogen fertilizer as ammonium sulphate which splitted to three applications and $40 \mathrm{~kg}$ $\mathrm{ha}^{-1} \mathrm{P}_{2} \mathrm{O}_{5}$ applicated with cultivation process. Irrigation system was conducted and controlled in order to preventing mixing of $\mathrm{Zn}$ levels. Weekly measurements were done from seeding to physiological maturity, which included Plant height, days to $50 \%$ flowering, days from 50\% flowering to physiological maturity, number of grains panicle ${ }^{-1}$, number of panicles plant ${ }^{-1}$, weight of 1000 grains (g), biological yield and grain yield. 
Table (1) some physical and chemical properties of the studied soil.

\begin{tabular}{|c|c|c|c|c|c|c|c|c|c|c|}
\hline \multicolumn{3}{|c|}{ PSD $\mathrm{g} \mathrm{kg}^{-1}$} & \multirow{2}{*}{ Textural class } & \multicolumn{7}{|c|}{ Soluble ions $\left(\mathrm{mmol} \mathrm{L}^{-1}\right)$} \\
\hline Sand & Silt & Clay & & $\mathbf{C a}^{2^{+}}$ & $\mathbf{M g}^{2^{+}}$ & $\mathrm{Na}^{+}$ & $\mathbf{K}^{+}$ & $\mathrm{HCO}_{3}^{-}$ & $\mathrm{Cl}^{-}$ & $\mathrm{SO}_{4}{ }^{2-}$ \\
\hline 34 & 549 & 417 & $\mathrm{SiC}$ & 0.98 & 0.41 & 0.39 & 0.03 & 3.1 & 0.43 & 0.9 \\
\hline pH & \multirow{2}{*}{$\begin{array}{r}\mathrm{EC}_{\mathrm{e}} \\
\mathrm{dS}^{-1}\end{array}$} & \multirow{2}{*}{$\begin{array}{c}\text { CEC } \\
{ }^{\text {cmolc kg }^{-1}}\end{array}$} & \multirow{2}{*}{ O.M } & $\mathrm{CaCO}_{3}$ & equivalent & \multicolumn{5}{|c|}{ Exchangeable cations } \\
\hline \multirow{3}{*}{7.75} & & & & Total & active & & & Cmol kg & & \\
\hline & \multirow{2}{*}{0.28} & \multirow{2}{*}{49.77} & \multicolumn{3}{|c|}{$\mathbf{g m ~ k g}^{-1}$} & $\mathbf{C a}_{\text {ex }}$ & $\mathbf{M g}_{\mathrm{ex}}$ & $\mathbf{K}_{\mathrm{ex}}$ & \multicolumn{2}{|c|}{$\mathbf{N} \mathbf{a}_{\mathrm{ex}}$} \\
\hline & & & 21 & 240 & 100 & 41.5 & 1.2 & 0.44 & & 16 \\
\hline
\end{tabular}

$* \mathrm{cmol}_{\mathrm{c}} \mathrm{kg}^{-1}=\mathrm{meq} / 100 \mathrm{~g}$ soil

\section{Results and Discussions:}

Table (2) indicated that zinc fertilizer application significantly increased the number of days from seeding to $50 \%$ flowering, days from $50 \%$ flowering to physiological maturity, plant height, and LAI. With increasing zinc fertilizer rates days to $50 \%$ flowering increased from 94.330 to 96.233 days in experiment 1 , in Exp. 2 such increase refers to positive response of local rice cultivar to zinc application and indicates to the lack of $\mathrm{Zn}$ availability, these results agree with results of [16]. Fig.1 and 2 show highly correlation $\left(\mathrm{r}^{2}=0.89\right.$ and 0.96$)$ between the length of vegetative growth and leaf area expanding Exp.1from 5.441 to 7.551 in

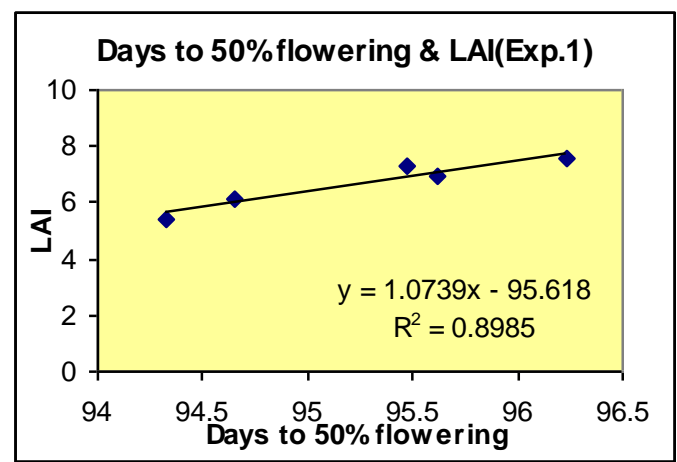

experiment 1 and from 5.46 to 7.32 in Exp.2

Table (2) Effect of different rate of Zn fertilizers applied to the soil on some agronomic traits of rice.

\begin{tabular}{|c|c|c|c|c|c|}
\hline $\begin{array}{l}\text { No. of } \\
\text { exp. }\end{array}$ & $\underset{1}{\operatorname{kg~Zn}} \mathrm{ha}^{-}$ & $\begin{array}{c}\text { Days to } \\
\mathbf{5 0 \%} \\
\text { flowerin } \\
\quad \mathrm{g}\end{array}$ & $\begin{array}{c}\text { Days } \\
\text { from } \\
\mathbf{5 0 \%} \\
\text { flowerin } \\
\text { g to } P M\end{array}$ & $\begin{array}{c}\text { plant } \\
\text { height } \\
\text { cm }\end{array}$ & LAI \\
\hline \multirow{5}{*}{$\begin{array}{l}\text { Zn } \\
\exp .1\end{array}$} & 0 & 94.330 & 37.50 & $\begin{array}{c}82.50 \\
0\end{array}$ & $\begin{array}{c}5.44 \\
1\end{array}$ \\
\hline & 12 & 94.650 & 37.43 & 87.33 & $\begin{array}{c}6.16 \\
3\end{array}$ \\
\hline & 24 & 95.616 & 37.38 & $\begin{array}{c}87.91 \\
6\end{array}$ & $\begin{array}{c}6.96 \\
8\end{array}$ \\
\hline & 36 & 95.469 & 37.86 & $\begin{array}{c}89.83 \\
3\end{array}$ & $\begin{array}{c}7.33 \\
0\end{array}$ \\
\hline & 48 & 96.233 & 38.28 & $\begin{array}{c}91.42 \\
3\end{array}$ & $\begin{array}{c}7.52 \\
5\end{array}$ \\
\hline \multirow{5}{*}{$\begin{array}{l}\mathrm{Zn+B} \\
\exp .2\end{array}$} & 0 & 96.383 & 38.15 & $\begin{array}{c}86.66 \\
6\end{array}$ & $\begin{array}{c}5.46 \\
0\end{array}$ \\
\hline & $12+B$ & 96.383 & 39.01 & $\begin{array}{c}87.66 \\
6\end{array}$ & $\begin{array}{c}5.86 \\
0\end{array}$ \\
\hline & $24+B$ & 97.016 & 39,41 & $\begin{array}{c}89.83 \\
3\end{array}$ & $\begin{array}{c}7.07 \\
0\end{array}$ \\
\hline & $36+B$ & 97.300 & 40.43 & $\begin{array}{c}92.16 \\
6\end{array}$ & $\begin{array}{c}7.36 \\
0\end{array}$ \\
\hline & $48+B$ & 97.250 & 42.28 & $\begin{array}{c}92.75 \\
0\end{array}$ & $\begin{array}{c}7.32 \\
0\end{array}$ \\
\hline
\end{tabular}

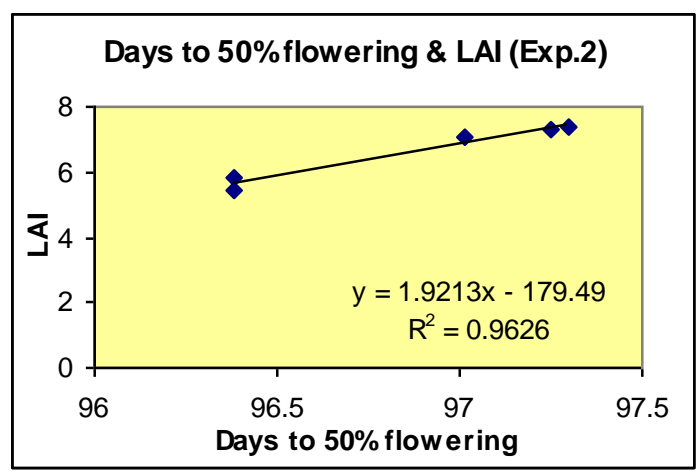

Fig. $(1,2)$ Relationship between LAI and Number of days to $50 \%$ flowering.

LAI indicates to the area exposed to sun light, which directly affect photosynthesis rate due to its direct effect on chlorophyll synthesis [4], this is closely related to dry matter accumulation per unit area, it means that final yield depends upon photosynthesis efficiency and the area exposured for photosynthesis [18]. In addition to that, it is considered as a second active source for the grain filling stage because the net products 
of photsynthesis which are synthesized during reproductive growth is used for grain yield by plants[18, 19].

Table (3) represents the significant difference in agronomic traits including, no.of grains panicle ${ }^{-1}$, no.of panicle $\mathrm{m}^{-2}$, sterility\%, biological yield, and kernel yield. No significant difference observed in 1000 grain weight [20] reported the same results in rice. No.of grains panicle ${ }^{-1}$ increased from 74.11 to 85.88 as the $\mathrm{Zn}$ level rised from 0 to $48 \mathrm{~kg} \mathrm{ha}^{-1}$, and maximum number of panicles $\mathrm{m}^{-2}$ was recorded by $36 \mathrm{~kg} \mathrm{ha}^{-1}$ which did not differ significantly from $48 \mathrm{~kg} \mathrm{ha}{ }^{-1}$, while $48 \mathrm{~kg} \mathrm{ha}^{-1}$ treatment recorded minimum percentage of sterility $(9.275 \%)$. The maximum biological yield and final yield were recorded by $48 \mathrm{~kg} \mathrm{ha}^{-1}$ treatment which was 11082.5 and $3862.5 \mathrm{~kg} \mathrm{ha}{ }^{-1}$ respectively, similar results recorded by [20]. Increasing the rate of $\mathrm{Zn}$ application correlated with agronomic traits related to the efficiency of physiological processes in the rice plants [15, 16, and 20]. Table (4) indicates to similar increase in yield characters due to $\mathrm{Zn}$ and $\mathrm{B}$ treatments, with the exception of sterility\%. There was an increase in its mean due to

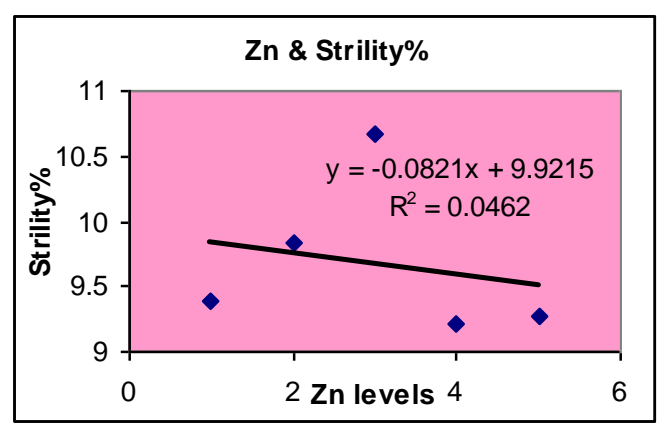

rising of fertilizer application from 0.15 to 0.27 and maximum rate was recorded from $\mathrm{f}_{3}$ which was 0.33 , that may be caused by the effect of Boron and cultivar sensitivity to $B$ application, and the result agreed with [17].

Table (3) effect of different rate of Zn fertilizers applied to the soil onyield characters.

\begin{tabular}{|c|c|c|c|c|c|c|}
\hline $\begin{array}{c}\text { Zn } \\
\text { leve } \\
\text { ls }\end{array}$ & $\begin{array}{c}\text { No.of } \\
\text { grain } \\
\text { panicl } \\
\mathrm{e}^{-1}\end{array}$ & $\begin{array}{c}\text { No. of } \\
\text { panicl } \\
\mathrm{e} \mathrm{m}^{-2}\end{array}$ & $\begin{array}{l}\text { Wt of } \\
\text { 1000gra } \\
\text { in } \mathrm{g}\end{array}$ & $\begin{array}{c}\text { Sterility } \\
\%\end{array}$ & $\begin{array}{l}\text { Biologic } \\
\text { al yield } \\
\mathrm{kg} \mathrm{ha}^{-1}\end{array}$ & $\begin{array}{c}\text { Yield } \\
\text { kg ha }^{-1}\end{array}$ \\
\hline $\mathbf{f}_{0}$ & 74.11 & $\begin{array}{c}321.0 \\
00\end{array}$ & 26.64 & 9.380 & $\begin{array}{c}8166.16 \\
6\end{array}$ & $\begin{array}{c}3101.3 \\
33 \\
\end{array}$ \\
\hline $\mathbf{f}_{1}$ & 77.72 & $\begin{array}{c}363.4 \\
16 \\
\end{array}$ & 26.78 & 9.833 & $\begin{array}{c}8580.33 \\
3 \\
\end{array}$ & $\begin{array}{c}3361.0 \\
00\end{array}$ \\
\hline $\mathbf{f}_{2}$ & 81.11 & $\begin{array}{c}378.1 \\
66\end{array}$ & 27.06 & 10.666 & $\begin{array}{c}9055.33 \\
3 \\
\end{array}$ & $\begin{array}{c}3590.0 \\
00\end{array}$ \\
\hline $\mathbf{f}_{3}$ & 82.83 & $\begin{array}{c}428.5 \\
83 \\
\end{array}$ & 27.10 & 9.222 & $\begin{array}{c}9687.00 \\
0 \\
\end{array}$ & $\begin{array}{c}3828.5 \\
00\end{array}$ \\
\hline $\mathbf{f}_{4}$ & 85.88 & $\begin{array}{c}426.0 \\
83\end{array}$ & 27.15 & 9.275 & $\begin{array}{c}11082.5 \\
00\end{array}$ & $\begin{array}{c}3862.1 \\
66\end{array}$ \\
\hline
\end{tabular}

Table (4) Effect of different rate of $\mathrm{Zn}$ and $B$ fertilizers applied to the soil on yield characters.

\begin{tabular}{|c|c|c|c|c|c|c|}
\hline $\begin{array}{c}\text { B } \\
\text { leve } \\
\text { Is }\end{array}$ & $\begin{array}{c}\text { No.of } \\
\text { grain } \\
\text { panicl } \\
\mathrm{e}^{-1}\end{array}$ & $\begin{array}{c}\text { No. of } \\
\text { panicl } \\
\text { e }^{-2}\end{array}$ & $\begin{array}{c}\text { Wt of } \\
\text { 1000gra } \\
\text { in g }\end{array}$ & $\begin{array}{c}\text { Sterility } \\
\%\end{array}$ & $\begin{array}{c}\text { Biologi } \\
\text { cal } \\
\text { yield } \\
\mathrm{kg} \mathrm{ha}^{-1}\end{array}$ & $\begin{array}{c}\text { Yield } \\
\mathrm{kg} \mathrm{h}^{-1}\end{array}$ \\
\hline B f $_{0}$ & $\begin{array}{c}75.80 \\
3\end{array}$ & $\begin{array}{c}328.3 \\
33\end{array}$ & 26.7 & 0.15 & 9022 & $\begin{array}{c}3100.3 \\
33\end{array}$ \\
\hline B f $_{1}$ & $\begin{array}{c}78.88 \\
6\end{array}$ & $\begin{array}{c}402.6 \\
66\end{array}$ & 26.68 & 0.14 & $\begin{array}{c}9573.83 \\
3\end{array}$ & 3250 \\
\hline B f $_{2}$ & $\begin{array}{c}80.69 \\
1\end{array}$ & $\begin{array}{c}402.3 \\
33\end{array}$ & 26.67 & 0.29 & 10290 & 3541 \\
\hline B f $_{3}$ & $\begin{array}{c}83.82 \\
6\end{array}$ & $\begin{array}{c}434.6 \\
66\end{array}$ & 27.06 & 0.33 & 10946 & 3701.5 \\
\hline B $_{4}$ & $\begin{array}{c}87.49 \\
6\end{array}$ & 430.5 & 27.17 & 0.27 & $\begin{array}{c}11720.6 \\
7\end{array}$ & 3791.5 \\
\hline
\end{tabular}

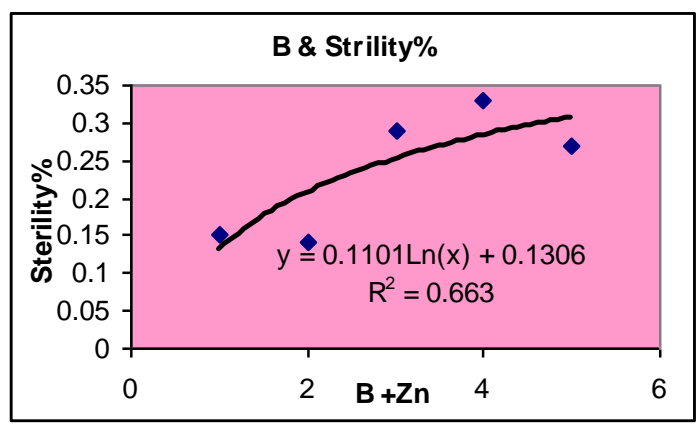

Fig. $(4,5)$ The relationship between Sterility\% and $\mathrm{Zn}$ levels(exp.no1)L,

The relationship between Sterility\% and Zn levels $+B$ (exp.no2)R

Table (5) Comparison between agronomic traits and yield characters studied in Exp.1 and Exp.2

\begin{tabular}{|c|c|c|c|c|c|c|c|c|c|c|}
\hline No. of exp. & - & 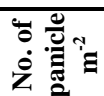 & 8 & 部。 & ئز & 焉 & & $\because$ & 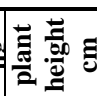 & \\
\hline & 401.65 & 383.449 & 26.946 & 11.072 & & 3557.2 & 95.257 & 37.690 & 87.7 & 6.68 \\
\hline & 40 & 399.696 & 26.856 & 17.685 & & 476.9 & 96.938 & 39.856 & 89.81 & 6.6 \\
\hline LSD & 3.163 & 416 & $\mathrm{NS}$ & 6.274 & 778 & 1.372 & 4.262 & 3.159 & 2.439 & $\mathbf{N S}$ \\
\hline
\end{tabular}


Results of table (5) indicated to significant differences between Exp.1 and Exp.2, in both the vegetative and reproductive characters, with exception in the 1000 grains weight and LAI. In relation to Exp.2, there was an increasing in the number of days to $50 \%$ flowering, No. of days from $50 \%$ flowering to physiological maturity, plant height that caused increase in biological yield, as well as number of panicle $\mathrm{m}^{-1}$ indicating to increasing in number of tillers, all these increases were associated with increasing Sterility\% from 11.072 to 17.685 . According to higher percentage of sterility in Exp.2, and in spite of increasing number of panicle. $\mathrm{m}^{-2}$ and No. of grains panicle ${ }^{-1}$, the final yield as shown from table (5) and figs. $(6,7)$ was higher in exp.1 (3557.2 $\left.\mathrm{kg} \mathrm{ha}^{-1}\right)$ than Exp.2(3476.866 kg ha $\left.{ }^{-1}\right)$, that was similar to results of [17].

\section{Conclusions:}

There were significant
differences in the studied vegetative
and reproductive growth characters
due to zinc fertilizer application,
indicating to the positive response of
local rice cultivar and the lack in
availability of the zinc element in
Sulaimani soil, but the results of
Exp.no.2 showed increasing in
sterility\% with boron foliar
application.

\section{Reference:}

1-De Datta, S.K.1981. Principles and particles of Rice Production. John Wiely and Sons.New York.

2-Qi,M.1987.A study on abundance and deficiency of zinc in paddy soil in Anqing Prefecture and the effect of zinc fertilizer application. Journal of Soil science of China 18(5):228-230.

3-Dobermann, A. and T. Fairhurst. 2000. Rice. Nutrient disorders \& nutrient management. Handbook series. Potash \& Phosphate Institute (PPI), Potash \& Phosphate Institute of Canada (PPIC) and International Rice Research Institute. $191 \mathrm{p}$.

4-Chen,W., X.Yang, Z.He, Feng, and F.Hu.2008. Differential changes in photosynthetic capacity, $77 \mathrm{~K}$ chlorophyll fluorescence and chloroplast ultrstructure between $\mathrm{Zn}$-efficient and $\mathrm{Zn}$-inefficient rice genotypes (Oryza sativa)under low zinc stress. Physiol Plant. 2008. 132(1):89-10.

5-IRRI. 2000. Nutritional Disorders and Nutrient management in Rice. Inter. Rice Res.Ins. Manila. Philippiens.

6-Salih,H.M., A.M. Hummadi, F.A. Hussain, and G.S. Tomma. 1987. Availability of major and some micronutrients in the central and southern Mesopotamia river plain in Iraq.J.Agri

7-Lazim,I.T., N.S.Murtadha and A.M.Salah.1989.Response of Wheat plant to zinc and determination of critical level for some Iraqi soils. JARWR8:81-91.

8-Al-Uqaili, J.K Ali, M.H., and A.W. Ali.1994. Influence of Phosphorous and zinc interaction on wheat nutition.Basrah J.Agric.Sci.7(1):349.

9-Sillanapaa. 1990. Chemical Analysis of Soils of North Iraq, FAO Bulletin No.63.

10-Singh,K., and Shukla U.C. 1985. Response of wheat to zinc application in different soils of semi-arid region.J.Indian Soc.Soil Sci.33:831-835.

11-Akram.M, R.A. Chudhry,Z.Ahmad, and G.U.Hag. 1995. Predicting DTPA soil test zinc and associated rice response to applied zinc. Commun.Soil Sci. Plant Anal. 26:258-259. 
12-Mahrana, D.P.,S.K. Sarengi, R.N.B. Singh, and M.H.Ali. 1993. Proceeding of the workshop on micronutrients. 22-23 January, 1992. Bhubaneswar, India.Pp228238.

13-Sagwal,O.P., Vijayrand, and V. Kumar. 1994. Effect of Balanced use of Fertilizers on productivity of basmati rice.Fertiliser News, 30(10):55-57.

14-Nand, R., and N.Ram.1996. Amelioration of zincstress by farmyard manure in rice-wheatcowpea system.Acta-AgronomicaHungarica 44(1):35-39.

15-Saleem,S.M., F.M. Choudhry, and S.Anjum.1996.Effect of $\mathrm{ZnSO}_{4}$ application on the ripening and yield of coarse rice.J. of Animal and Plant Sciences, Pakistan.6 (12):27-29.

16-Ali, N.S., J.K.Al-Uqaili, and B.H. Al-Ameri. 2001. Efficiency of some Zinc fertilizers in calcareous soil.the Iraqi Journal of Agriculture sciences. 32(6):197-206.

17-Al-Kawaz, G.M.,R. Al-Badrawy, W.Al-Shamaa, and R. Maaruf. 1976.Relationship between seeding date,Boron effect and unfertility, Yield componens, Yield and Quality of Rice(Oryza sativa L.) Technical Bulletin No.20 Sci.Res. Foundation-Iraq.

18-Stoskof,N. 1989. Crop Production understanding. Translated to Arabic. Univ. of Mosul.

19-Mohammed, A.A. 2002. Effect of plant population and two methods of cultivation on growth and yield of four local varieties of rice (Oryza sativa L.) in sulaimani region. . Msc thesis College of Agriculture- Univ. of Sulaimani.

20-Yakan, H., M.A.Gurbuz, and F. Avshar.2001. The effect of zinc application on rice yield and some agronomic characters. Rural service, Ataturk Research Institute(Turky).

\section{استجابة الرز المحلي لاضافات من الزنك و البورون}

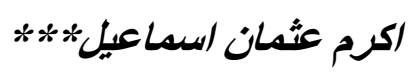

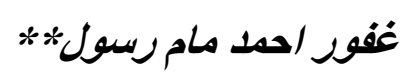

*قتم المحاصيل الحقلية ، كلية الزر اعة-جامعة السليمانية .

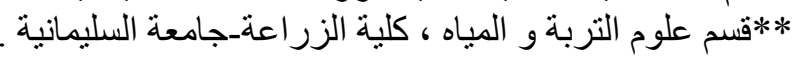

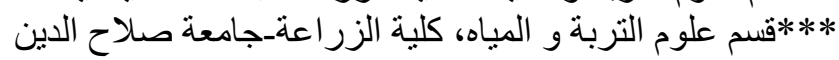

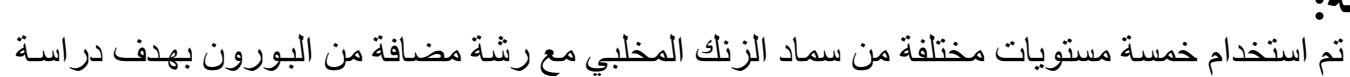

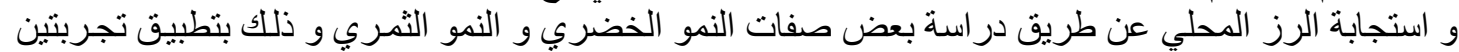

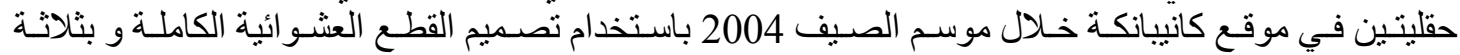

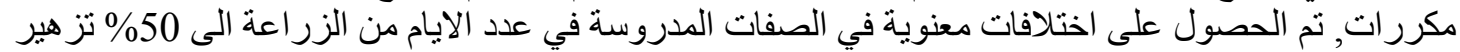

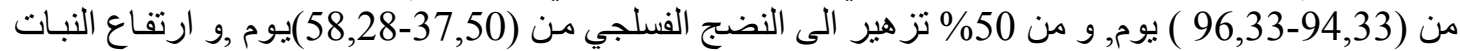

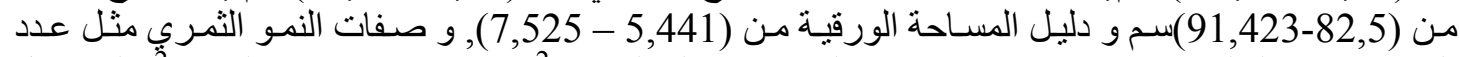

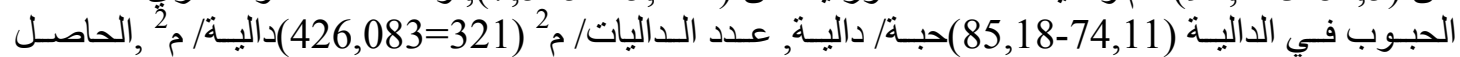

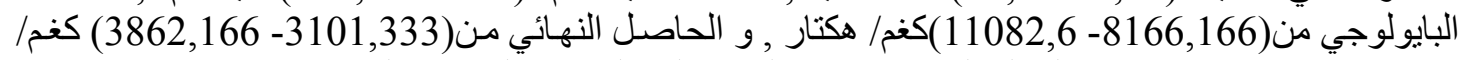

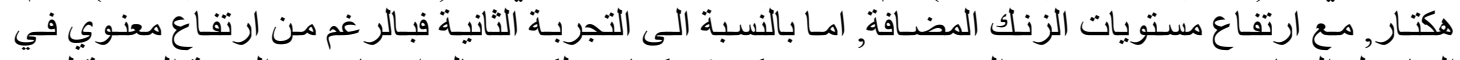

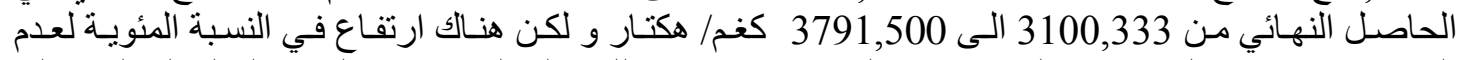

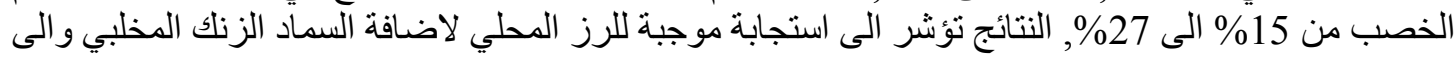
نقص في جاهزية عنصر الزنك في ترب منطقة السليمانية. 